\title{
Optimization of financing investments in a power-generation company
}

\author{
M. Khodorovsky, A. Domnikov \& P. Khomenko \\ Ural Federal University after the first President of Russia B. N. Yeltsin, \\ Russia
}

\begin{abstract}
Attracting investment in the Russian energy industry is a necessary condition for improving the competitiveness of energy companies. It is important to create an investment budget financing structure, in which the weighted average cost of funds will be minimal, and the amount of resources drawn from each source to fit the current market trends and financial sustainability criteria power generation company. This paper discusses problems of investment financing optimization of a power generation company, a proposed optimization model of investment financing and calculated parameters for the optimization of the investment program in the example of a Russian power generating company. Keywords: power generation company, investment, optimization model, financial sustainability, common stocks, preferred stocks, loans, bonds, project financing funds, leasing.
\end{abstract}

\section{Introduction}

Energy is an important infrastructure sector of the economy. The backbone is a part of modern energy generation - the electricity and heat production, on the basis of the existing power generating companies. One of the most pressing problems facing the Russian power generation companies is the problem of attracting investment. This is due to the necessity to make large capital investments to upgrade worn-out assets in power generation.

Depreciation of production capacity in the energy sector by some estimates is $60 \%$. Further deterioration is expected obsolescence of generating capacity, and by 2020 the volume of disposed fixed assets in power generation could reach 
$75 \%$ [1]. The solution to this problem requires the use of resources significant investment in the energy generation sector.

Attracting investment resources requires the involvement of several sources. It is important to create a structure of investment budget financing, in which the weighted average cost of funds will be minimal, and the amount of resources drawn from each source, adequate investment needs and criteria of financial sustainability power generation company.

The problem of optimizing the financial structure of the company is considered a fundamental work of leading foreign and domestic scholars, such as Sharp et al. [2] Brigham and Erhard [3], Blank [4], Lukasiewicz [5]. Based on the research in this area and the specifics of a power generating industry, an optimization model of the investment program financing power generation company.

\section{The structure of investments financing and financial sustainability}

Suppose power generating company sells $i$ investment projects. These projects are financed from $\mathrm{j}$ sources of investment financing power generation company. Each source of funding can be attributed to their own or borrowed funds. We denote this feature with a $k$.

Investment projects of power generating companies are different size of the budget, the level of risk, cost, and security and liquidity commitments and other factors determining the value of the resources. Therefore, for each $i$ of investment projects financed by the $\mathrm{j}$-th source is possible to determine the value of resources $c_{i j}$. Each investment project meets a certain level of interest rates on funding sources, in which the realization of the investment project is not economically viable, due to the excess of expenditure over the discounted present value of the project.

When optimizing the financing of investments necessary to consider the impact of the financing structure for the financial sustainability of a power generating company. To this end, the model was introduced factor of financial sustainability, which is an integral measure of financial sustainability [6] Energy Generating Company (1). Evaluation of the model parameters was carried out on the basis of empirical data about the companies of the energy sector in Russia.

$$
G=0.627 \times F 1+0.796 \times F 2+0.410 \times F 3+0.428 \times F 4+0.316 \times F 5+0.282 \times F 6
$$

where $\mathrm{G}$ - an integral index of financial sustainability power generating company, F1 - leverage levels, F2 - interest coverage ratio, F3 - working capital ratio of its own sources of funding, F4 - cash ratio, F5 - cost-benefit ratio of own funds, F6 - return on EBITDA.

It was found that the effect of leverage on the sources of financial sustainability is not linear (Fig. 1). Increasing the proportion of debt in the structure of financing sources to a certain level leads to increased financial sustainability due to the positive effect of financial leverage. However, a further 
increase in leverage reduces the financial sustainability of a power generating company due to the reduction of autonomy and increase leverage. To account for this dependence in the optimization model will be introduced by non-linear constraint associated with the dependence of the financial sustainability of the proportion of borrowing.

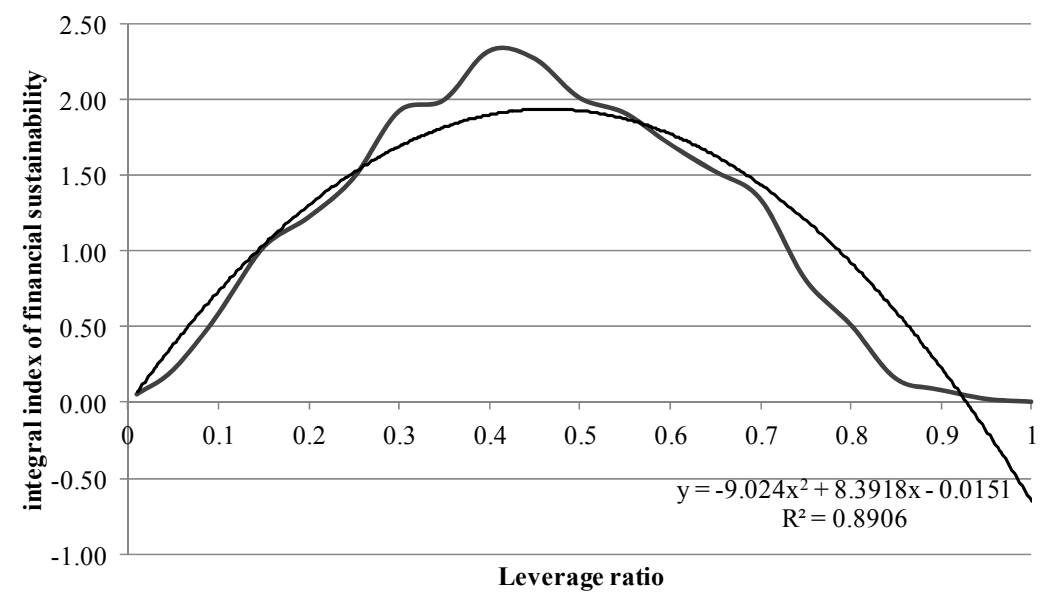

Figure 1: The relationship between the financial sustainability of power generating companies and leverage ratio.

\section{Optimization model}

Determine the value of $x_{j}$ as a proportion of funds raised from the $\mathrm{j}$-th source at a given level of interest rates in the total amount of resources involved.

The function minimizes the cost of raised funds to finance the investment program (2):

$$
F(w)=\sum_{j} \sum_{k} r_{j k} \times x_{j k} \rightarrow \min
$$

where $r_{j k}$ - the cost of the resources involved power generating company of the $\mathrm{j}$-th source k-type, $x_{j k}$ - the share of the $\mathrm{j}$-th source of k-type investment program in the budget.

An optimization model will include the following balances and limitations:

1. Restrictions on the cost of financing the investment program (3)

$$
\sum_{i} \sum_{j} \sum_{k} c_{i j} \times x_{j k} \leq b_{i}
$$


where $b_{i}$ - the maximum cost of the resources involved to finance the $\mathrm{i}$-th source, $c_{i j}$ - cost of funds raised from the i-th source of equity financing for the $\mathrm{j}$-th project.

2. Budget balance of the investment program (4)

$$
\sum_{i} x_{j}=1
$$

3. Non-linear constraint on the ratio of debt to equity (5)

$$
\sum_{i} \sum_{j} \sum_{k}\left(a_{i j} \times x_{j k}+d_{i j} \times x_{j k}{ }^{2}+e_{i j}\right) \geq G_{i}
$$

where $\mathrm{G}$ - an integral index of financial sustainability power generating company, $a_{i j}, d_{i j}, e_{i j}$-empirical coefficients of the model.

4. Restrictions on the amount of debt (6)

$$
S_{i \min } \leq \sum_{i=k} x_{i} \leq S_{i \max }
$$

where $S_{i \min }$ - the lower limit value of debt, $S_{i \max }$ - the upper limit on the amount of borrowed funds.

4. Limits on the amount of the investment project (7)

$$
0 \leq x_{j} \leq 1
$$

Model optimization of the structure of the investment budget power generating company in a formal statement takes the form (8):

$$
\left\{\begin{array}{l}
F(w)=\sum_{j} \sum_{k} r_{j k} \times x_{j k} \rightarrow \min \\
\sum_{i} \sum_{j} \sum_{k} c_{i j} \times x_{j k} \leq b_{i} \\
\sum_{i} \sum_{j} \sum_{k}^{k}\left(a_{i j} \times x_{j k}+d_{i j} \times x_{j k}{ }^{2}+e_{i j}\right) \geq G_{i} \\
S_{i \min } \leq \sum_{i=k} x_{i} \leq S_{i \max } \\
\sum_{i} x_{j}=1 \\
0 \leq x_{j} \leq 1 \\
i=\overline{1, m}, j=\overline{1, n}
\end{array}\right.
$$

The presented model is a nonlinear optimization problem, since the constraint system contains a non-linear component. 
Consider the solution of the problem of optimizing the structure of the investment budget power generation company as an example of regional power generating company TGK-9. The main sources of financing of the investment program generating company can be divided into its own, borrowed and borrowed funds (Fig. 2). By its own assets include accumulated retained earnings and reserves of the enterprise. The funds raised are financial resources received from the additional issuance of common and preferred shares and government funding. Borrowings - obtained on the terms of payment, maturity, repayment to creditors. These include bank loans, investment loans, project financing funds, leasing, factoring, forfeiting, bonds and securitization.

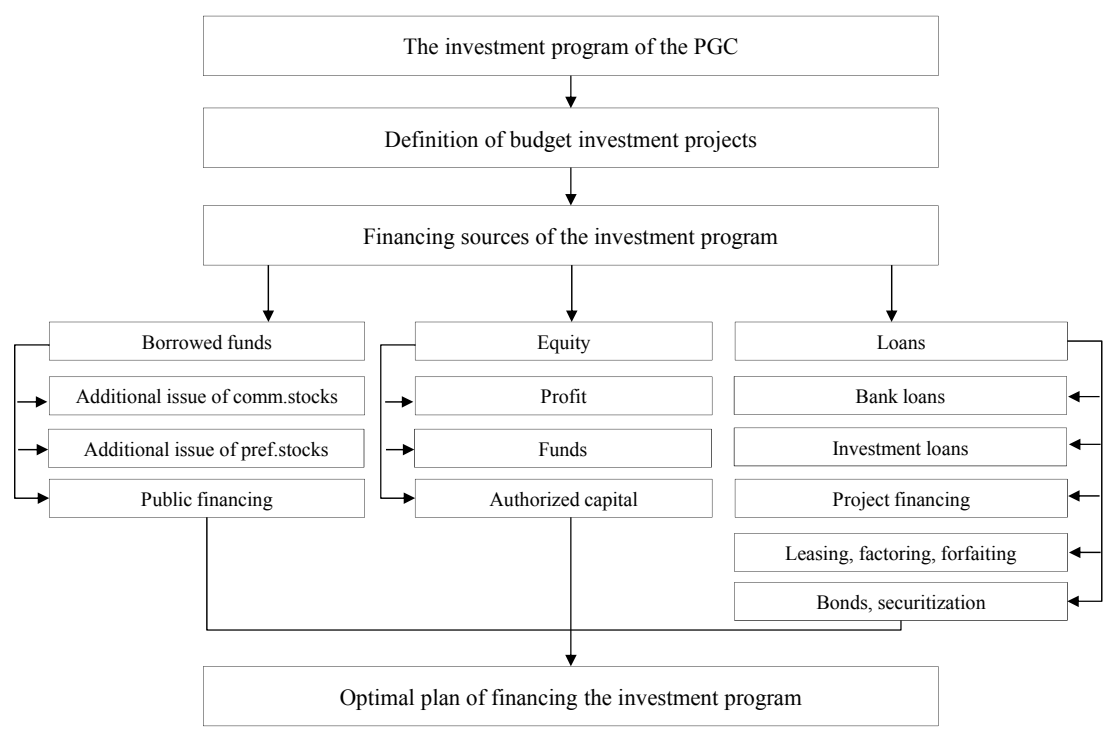

Figure 2: Optimization mechanism of investment financing power generation company.

Each source of financing corresponds to the level of value, which is determined by the financial costs. Holders of common and preferred stock dividends are paid - the net profit of the company during the reporting period. On bonds coupon yield, bank loans, investment loans, project finance and leasing - interest payments. The cost of securitization is also dependent on the coupon rate, as well as organizational and management costs associated with the activities of the SPV.

In determining the optimal structure of funding sources is important to quantify the value of the cost of resources drawn from each funding source. Price of financial resources is one of the key factors shaping the structure of the financing of the investment project. At the same time, no less important factors in determining the structure of funding is management flexibility (flexibility), the degree of risk (risk), expected returns and their variability (income), maintaining control over the business (control) and time of the operation (timing) [6]. Factors 
affecting the cost of the resources involved power generating company to finance the investments listed in the table.

\section{Financing optimization of the investment program example}

According to the investment program of TGC-9 in the company implemented 11 investment projects. The data about the name of projects, their content and the costs of implementation are presented in Table 1.

Table 1: $\quad$ The investment program of TGC-9.

\begin{tabular}{|l|l|}
\hline \multicolumn{1}{|c|}{ Investment project } & \multicolumn{1}{c|}{ Budget, mln. } \\
\hline Reconstruction of Perm HPP-6 & 7429 \\
\hline Reconstruction of Perm HPP-9 & 7511 \\
\hline Construction of the New-Bereznikovskaya HPP & 10482 \\
\hline Reconstruction Nizhneturinskaya GRES power plant & 17000 \\
\hline Construction Novobogoslovskaya HPP & 10040 \\
\hline Construction of HPP Academic & 10565 \\
\hline
\end{tabular}

Assessment of the level of dividend payments, in order to calculate the cost of financing investments through an additional issue of ordinary shares was carried out on the basis of the level of dividends on common stock main participants of the stock market, owned energy generating sector.

Table 2: $\quad$ The level of dividends major energy companies.

\begin{tabular}{|l|l|l|l|}
\hline \multicolumn{1}{|c|}{ Company name } & \multicolumn{3}{c|}{ Dividends, \% } \\
\cline { 2 - 4 } & 2009 & 2010 & 2011 \\
\hline RusHydro & $\mathrm{H}$ & 0.64 & 1.01 \\
\hline Inter RAO & 0 & 0.04 & 0 \\
\hline E. On Russia & 0 & 0 & 2.54 \\
\hline WGC-2 & 0 & 0.32 & 0.2 \\
\hline Enel WGC-5 & 0 & 0 & 0 \\
\hline Mosenergo & 0.4 & 0.75 & 1.84 \\
\hline Irkutskenergo & 1.1 & 0.55 & 0.71 \\
\hline
\end{tabular}

Estimates of the value and volume of financing of the investment program by issuing ruble bonds can be given on the basis of calculating the industry average 
performance and the value of the coupon bonds outstanding. The raw data used for the calculation are given in the table.

Table 3: The coupon rate of the territorial generating companies.

\begin{tabular}{|l|c|c|c|c|}
\hline $\begin{array}{l}\text { Bond } \\
\text { issue }\end{array}$ & Maturity & Coupon & $\begin{array}{l}\text { Yield to } \\
\text { maturity }\end{array}$ & $\begin{array}{l}\text { Total } \\
\text { outstanding, } \\
\text { mln }\end{array}$ \\
\hline TGC-1-1 & 11.03 .2014 & 7.6 & 8.85 & 4000 \\
\hline TGC-1-2 & 01.07 .2014 & 6.7 & 8.19 & 5000 \\
\hline TGC-1-3 & 14.12 .2021 & 7.6 & 7.74 & 2000 \\
\hline TGC-1-4 & 14.02 .2022 & 7.6 & 7.74 & 2000 \\
\hline TGC-2-1 & 17.09 .2013 & 9 & 47.23 & 5000 \\
\hline TGC-5-1 & 06.10 .2017 & 8.75 & 10.15 & 5000 \\
\hline TGC-6-1 & 24.08 .2017 & 8.3 & 9.77 & 5000 \\
\hline TGC-9-1 & 07.08 .2017 & 8.1 & 10.35 & 7000 \\
\hline Avg.: & & 7.96 & 13.75 & 4375 \\
\hline
\end{tabular}

The average coupon rate is $7.96 \%$ per annum, while the average yield on bonds with 5 -year maturity is more than $8 \%$. The average volume of bonds in circulation is $4,375 \mathrm{mln}$. Thus, for the financing of the investment program can accommodate commercial paper worth 5 billion rubles with a yield of $8 \%$ per annum.

Evaluation of interest rates on bank and investment lending, leasing was made on the basis of the Bank of Russia and the average indicators of the risk of each project [7].

The resulting model parameters to optimize the financing of investment projects from each source are presented in Table 4. In the model, the ability to finance investment projects with an additional issue of shares $(\mathrm{j}=1)$, bonds $(\mathrm{j}=2)$, bank loans $(\mathrm{j}=3)$, investment lending and project financing $(\mathrm{j}=4)$ and leasing $(\mathrm{j}=5)$.

In assessing the relationship between the empirical parameters integral indicator of financial sustainability and leveraged investment in the budget model was obtained non-linear constraint, presented in Table 5. In this paper have been optimized sources of investment financing for three different values of the coefficient of financial sustainability: not less than 0.58 , minimum 1.48 , not 2.05 below.

As a result of the optimization problem on the basis of the model (7) and the data in Tables 1, 4 and 5 received several optimal financing structures investment, based on the different values of the financial sustainability (Figs 3, 4 and 5). 
52 Energy Production and Management in the 21st Century, Vol. 1

Table 4: The cost of financing investment projects from various sources.

\begin{tabular}{|c|c|c|c|c|c|}
\hline \multirow{2}{*}{$\mathrm{i}$} & \multicolumn{5}{|c|}{$\mathrm{j}$} \\
\cline { 2 - 6 } & 1 & 2 & 3 & 4 & 5 \\
\hline 1 & 0.01 & 0.08 & 0.12 & 0.1 & 0.12 \\
\hline 2 & 0.01 & 0.09 & 0.125 & 0.15 & 0.131 \\
\hline 3 & 0.03 & 0.095 & 0.128 & 0.18 & 0.14 \\
\hline 4 & 0.02 & 0.105 & 0.13 & 0.122 & 0.148 \\
\hline 5 & 0.04 & 0.1 & 0.131 & 0.142 & 0.138 \\
\hline 6 & 0.04 & 0.101 & 0.128 & 0.14 & 0.14 \\
\hline
\end{tabular}

Table 5: Empirical evaluation of the model index of financial sustainability.

\begin{tabular}{|c|r|r|c|c|c|c|}
\hline \multirow{2}{*}{$\mathrm{i}$} & \multicolumn{3}{|c|}{$\mathrm{j}$} & \multicolumn{3}{c|}{$\mathrm{G}$} \\
\cline { 2 - 7 } & 1 & 2 & 3 & 1 & 2 & 3 \\
\hline 1 & -8.207 & 7.266 & -0.004 & 0.58 & 1.48 & 2.05 \\
\hline 2 & -9.977 & 7.675 & -0.014 & 0.58 & 1.48 & 2.05 \\
\hline 3 & -9.5 & 5.457 & -0.014 & 0.58 & 1.48 & 2.05 \\
\hline 4 & -7.253 & 7.225 & -0.01 & 0.58 & 1.48 & 2.05 \\
\hline 5 & -7.237 & 4.45 & -0.012 & 0.58 & 1.48 & 2.05 \\
\hline 6 & -7.337 & 6.732 & -0.007 & 0.58 & 1.48 & 2.05 \\
\hline
\end{tabular}

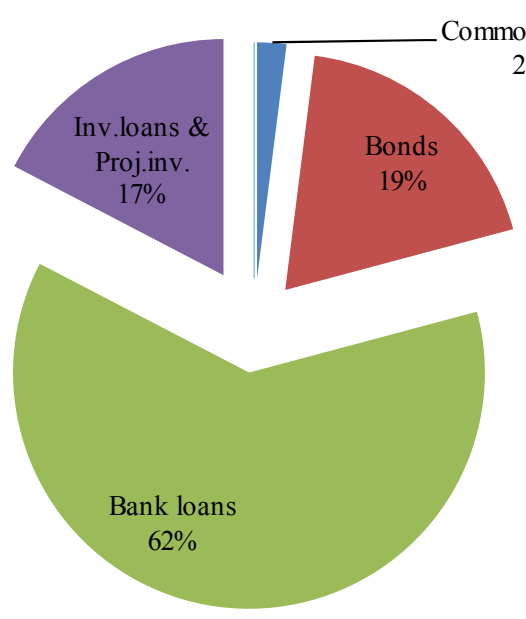

Figure 3: The results of optimization of funding investment program TGK-9 $(\mathrm{G}=0.58)$. 


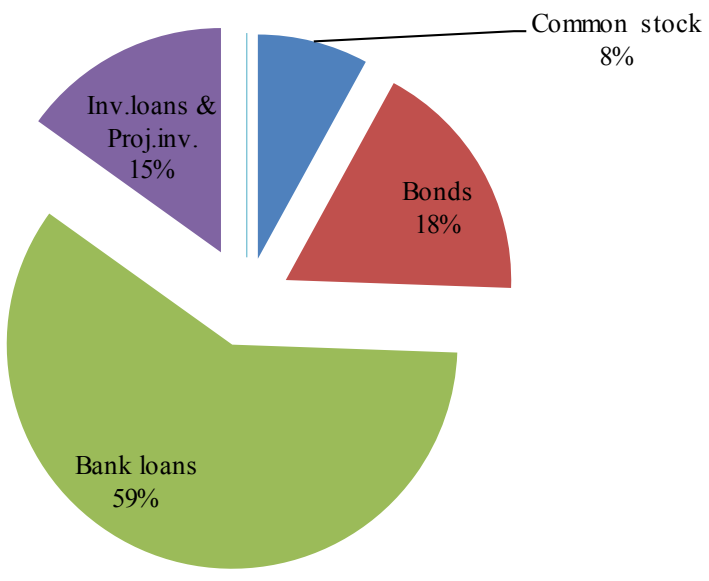

Figure 4: The results of optimization of funding investment program TGK-9 $(\mathrm{G}=1.48)$.

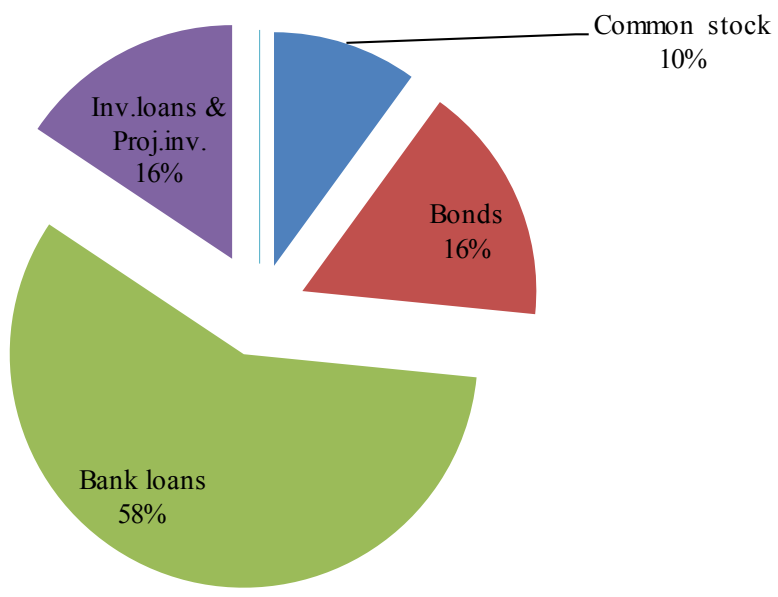

Figure 5: The results of optimization of funding investment program TGK-9 $(\mathrm{G}=2.05)$.

\section{Conclusion}

The problem of investment for energy companies is one of the most important. Investments can be financed from internal (stocks, reserves and profit) and external sources (long-term and short-term borrowings, accounts payable). To reduce the costs of maintenance involved resources necessary to achieve the optimal structure of financing investment. These tasks could be performed by non-linear optimization techniques to optimize the structure of investment 
financing power generation company with regard to its financial stability. Application of this method allows to achieve a financial structure in which is received the minimum average cost of funding under the given constraints defined by the budget of investment projects and the requirements for financial stability power generation company.

\section{References}

[1] Annual Report 2011 of JSC "TGC -9"

[2] William Sharpe, Gordon J. Alexander, Jeffrey W Bailey Investments. Infra - M: Moscow, 1997. p. 442.

[3] Eugene F. Brigham, Michael C. Ehrhardt: Financial Management. 10th ed. - Peter: St. Petersburg, 2009. - 960

[4] Blank I.A. Fundamentals of Financial Management Text.: 2 t, 2nd ed., Rev. and add. - Elga, Nick Center: Kiev, 2004.

[5] Lukasiewicz I.J. Financial Management - 2nd ed., Rev. and add. Penguin Books: Moscow, 2010. 768.

[6] Kanke A.A. Koshevaya I.P. Analysis of financial and economic activity of the -2 nd ed., Rev. and add. Forum: INFRA-M: Moscow, 2007. -288 p.

[7] The weighted average interest rate on loans to credit institutions to individuals and non-financial institutions in rubles. Official site of the Bank of Russia. http://www.cbr.ru/statistics/print.aspx?file=b_sector /dii_rates_2- 7.htm \& pid = cdps \& sid = ITM_60399

[8] Domnikov A. Competitive development of cogeneration energy. Ural State Technical University: Ekaterinburg - 364 p., 2008.

[9] Volgina O.A., Golodnaya N.Y., Odiyako N.N., Schumann G.I. Mathematical modeling of economic processes and systems. - Publishing house VSUES 2008: Vladivostok - $84 \mathrm{p}$.

[10] Holod N.I. Kuznetsov A.V., Zhihar Y.N. Economic-mathematical methods and models -2 nd ed. - Belarusian State Economic University: Minsk, 2000. $-412 \mathrm{p}$.

[11] Orlova I.V., Polovnikov V.A. Economics and Mathematical Methods and Models: Computer Modeling. High school textbook: Moscow, 2007. - 365 p.

[12] Akulich I.L. Mathematical programming examples and problems Higher School: Moscow, 1986. - 319 p.

[13] Sheremet A.D. Megashev E.V. Methods of financial analysis of business 2nd ed., Rev. and add. - Infra- M: Moscow, 2009. - 208 p.

[14] Shevchuk D.A. Finance companies - Moscow, 2009. - 209 p. 